\title{
Metabolic syndrome and professional aptitude
}

\section{Zespót metaboliczny a przydatność zawodowa}

\author{
Dorota Rębak ${ }^{1}$, Edyta Suliga², Stanisław Głuszek ${ }^{1,3}$ \\ ${ }^{1}$ Department of Surgery and Surgical Nursing with Research Laboratory, Institute of Medical Sciences, Faculty of Medicine \\ and Health Sciences, Jan Kochanowski University, Kielce, Poland \\ Head of the Department: Prof. Stanisław Głuszek MD, PhD \\ 2Department of the Prevention of Alimentary Tract Diseases, Institute of Nursing and Obstetrics, Faculty of Medicine and Health \\ Science, Jan Kochanowski University, Kielce, Poland \\ Head of the Department: Prof. Grażyna Rydzewska MD, PhD \\ ${ }^{3}$ Department of Clinical General, Oncological and Endocrinological Surgery, Regional Hospital, Kielce, Poland \\ Head of the Department: Prof. Stanisław Głuszek MD, PhD
}

Key words: metabolic syndrome, occupational activity, professional aptitude.

Słowa kluczowe: zespół metaboliczny, praca zawodowa, przydatność zawodowa.

\begin{abstract}
The development of civilisation has resulted in a growing problem of metabolic diseases, including metabolic syndrome. Scientific studies show that this disease is an epidemic of the $21^{\text {st }}$ century. Metabolic syndrome is a collection of mutually related metabolic factors, such as obesity, impaired glucose tolerance, lipid disorders, arterial hypertension, and pro-inflammatory and prothrombotic state, increasing the risk of the development of atherosclerosis and type 2 diabetes, and their cardiovascular complications. Considering the scale of the prevalence of metabolic syndrome, the causes of its development and diagnostic criteria are the main contemporary directions of scientific research. The study presents an analysis of the relevant literature with respect to terminology, diagnostic criteria, and pathogenesis of metabolic syndrome. The second section of the study discusses the degree of epidemiological risk due to metabolic syndrome and its individual components among the adult Polish population. The effect of this phenomenon on professional competence is also taken into consideration.
\end{abstract}

\section{Streszczenie}

Wraz z rozwojem cywilizacji zaczęto obserwować narastający problem chorób metabolicznych, do których zalicza się zespół metaboliczny. Badania naukowe dowodzą, że choroba ta jest epidemią XXI wieku. Zespół metaboliczny to zbiór wzajemnie powiązanych czynników metabolicznych, takich jak otyłość, upośledzona tolerancja glukozy, zaburzenia lipidowe, nadciśnienie tętnicze, stan prozapalny i prozakrzepowy, zwiększający ryzyko rozwoju miażdżycy i cukrzycy typu 2 oraz ich powikłań sercowo-naczyniowych. Ze względu na skalę problemu zespołu metabolicznego przyczyny jego występowania i kryteria diagnostyczne stanowią współczesne kierunki badań naukowych. W opracowaniu dokonano analizy literatury przedmiotu w zakresie terminologii, kryteriów diagnostycznych i patogenezy zespołu metabolicznego. W drugiej części pracy określono stopień zagrożenia epidemiologicznego zespołem metabolicznym i jego poszczególnymi składowymi u osób dorosłych w polskiej populacji oraz poddano rozważaniom wpływ tego zjawiska na sprawność zawodową.

\section{Introduction}

During five centuries (XVII-XXI) the nomenclature, definition, as well as the aetiology and pathogenesis, of metabolic syndrome have evolved, and the growing epidemiological problem has been named as an epidemic of the $21^{\text {st }}$ century. It has become one of the greatest challenges in public health programmes worldwide. The scale and degree of publicising the problem, and its character and clinical effects, motivated the authors of this study to undertake a review of the relevant literature from the aspect of terminol- ogy, diagnostic criteria, and pathogenesis of metabolic syndrome. Special attention is paid to the degree of epidemiological risk due to metabolic syndrome and its individual components among the adult Polish population. In addition, the effect of this phenomenon on occupational efficiency is investigated.

The first reports concerning metabolic syndrome were associated with the name of the Dutch scientist Nicolas Tulp and his work entitled: 'Observationum medicarum libri tres', published in 1641, in which Tulp presented a case of hypertriglyceridaemia, its causes, and consequences [1, 2]. In 1761 Joannes 
Babtista Morgani observed and documented the relationship between abdominal obesity, and symptoms and complications of arterial hypertension (headache, enlargement of the heart and heart failure, pulmonary oedema, and cerebral stroke) (De sedibus et causis morborum per anatomen indagatis) [3]. In 1923 Eskil Kylin in the German journal 'Zentralblatt für innere Medizin' suggested that the cluster of arterial hypertension, hyperglycaemia, and hyperuricaemia creates a pathological syndrome [4]. The suggestions concerning the existence of a separate syndrome resulting from three mutually dependent metabolic disorders - hyperlipidaemia, obesity, and diabetes - was confirmed by Italian researchers Piero Avogardo and Gaetano Crepali in 1965 at a meeting of the European Association for the Study of Diabetes, and 2 years later the concept of 'plurimetabolic syndrome' was introduced [5]. The original division into primary diabetes (in childhood and adulthood separately) and in combination with other diseases was made by the Polish scientist Jakub Węgierko (1889-1960). Węgierko compiled the second type of diabetes closely related with metabolic syndrome with such disorders as: obesity, arterial hypertension, atherosclerosis, gout, and cholecystolithiasis, indicating that the above-mentioned diseases are not the direct cause of this type of diabetes. This is a syndrome typical of adulthood [6, 7]. In 1966, a French researcher named the diagnosed disorders as follows: diabetes, gout, and hypertriglyceridaemia a 'metabolic trisyndrome' (trisyndrome metabolique) [8]. In 1968, the German physicians Mehnerti and Kuhlmann formulated the concept of 'wealth syndrome' (Wohlstand syndrome), characteristic of the lifestyle and mode of nutrition of Western populations. According to them, this syndrome predisposed for disorders of a metabolic nature, i.e. arterial hypertension, diabetes, and dyslipidaemia and, in consequence, to ischaemic heart disease [8].

The term 'metabolic syndrome' was first used by Hanefeld and Leonhart in the scientific report 'Das metabolische Syndrome'. According to these researchers, metabolic syndrome is the collection of: obesity, hyperlipidaemia, diabetes, gout, and arterial hypertension, and its development is favoured by: an excessive consumption of food products, lack of physical activity, and genetic predisposition. The syndrome also increases the incidence of ischaemic heart disease, fatty liver, and cholelithiasis [9].

Gerald Reaven (1988) in his work: 'Role of insulin resistance in human disease' proposed to name a complex of cardiovascular risk factors 'syndrome $\mathrm{X}^{\prime}$ and suggested that insulin resistance plays a crucial role in the pathogenesis of this syndrome. The researcher disregarded obesity, considering that syndrome $\mathrm{X}$ may also occur in non-obese individuals [10]. However, Professor Norman Kaplan (1989) indicated central obesity, while eliminating insulin resistance. Reaven called the four-risk factor group, i.e. arterial hypertension, hypertriglyceridaemia, glucose intolerance, and visceral obesity complicated by a considerable amount of adipose tissue, the 'deadly quartet' [11]. In subsequent years, there new terms were coined, including: 'insulin resistance syndrome' - De Fronzo and Ferranini (1991) - suggesting a significant relationship between insulin resistance and the previously-mentioned disorders. Lemieux proposed 'hypertriglyceridaemic waist' - waist circumference $\geq 90 \mathrm{~cm}$, and hypertriglyceridaemia $>176 \mathrm{mg} / \mathrm{dl}$ ( $2 \mathrm{mmol} / \mathrm{l})$. Lemiux defined a metabolic triad: hyperinsulinaemia, elevated levels of apolipoprotein B, and LDL cholesterol. The terms more rarely used were diabesity and chaos syndrome [12-14].

Metabolic syndrome (MetS) has become one of the terms most frequently used in the domain of medical sciences; nevertheless, the adoption of a consensus concerning the issue of defining, and criteria for diagnosing, metabolic syndrome remain a problem to be solved. Activities in this area were undertaken by many organisations, frequently distinguishing different components, pathological agents, and conditions indispensable or diagnosing this pathological entity.

\section{Definitions and criteria}

In the definition by the World Health Organisation (WHO), which was the first to establish in 1998 the diagnostic criteria of the metabolic syndrome (Table 1), the features of insulin resistance were indicated as the major criteria. According to the WHO, these criteria include: type 2 diabetes, elevated level of fasting glucose, impaired glucose tolerance, or increased concentration of insulin. An additional criterion was the occurrence of two out of four disorders: arterial hypertension, elevated level of triglycerides, low HDL cholesterol level, and obesity and microalbuminuria [15]. In routine and epidemiological studies, the diagnosis of the metabolic syndrome should be made in a simple and available way. The criteria defined by the WHO are conditioned by performing specialist diagnostic tests, which, in this context, may indicate the disadvantages of this definition [16].

Experts from the European Group for the Study of Insulin Resistance (EGIR) consider that insulin resistance is the main pathogenetic factor in insulin resistance, and define this disorder by the term 'insulin resistance syndrome'. In order to diagnose this syndrome according to the EGIR criteria (Table 2) it is required that insulin resistance or hyperinsulinaemia be diagnosed. In addition, it is necessary to confirm at least two of the following disorders: abdominal obesity, arterial hypertension, elevated level of triglycerides or low HDL cholesterol level, and fasting hyperglycaemia. The EGIR attaches importance to abdominal obesity determined based on waist circumference. The advantage of the adopted criteria is also 
Table 1. Definition of metabolic syndrome according to the WHO [15]

\begin{tabular}{|c|c|}
\hline & Any of the following components: \\
\hline \multirow{4}{*}{$\begin{array}{l}\text { Indispensable } \\
\text { criteria }\end{array}$} & $\begin{array}{l}\text { Type } 2 \text { diabetes } \\
\text { level of fasting glucose } \geq 126 \mathrm{mg} / \mathrm{dl}(7 \mathrm{mmol} / \mathrm{l}) \text { or glycaemia } 2 \mathrm{~h} \text { after glucose load } \geq 200 \mathrm{mg} / \mathrm{dl} \\
(11.1 \mathrm{mmol} / \mathrm{l})\end{array}$ \\
\hline & $\begin{array}{l}\text { Impaired glucose tolerance } \\
\text { level of fasting glucose }<126 \mathrm{mg} / \mathrm{dl}(7 \mathrm{mmol} / \mathrm{l}) \text { or glycaemia } 2 \mathrm{~h} \text { after glucose load } \geq 7.8 \mathrm{mmol} / \mathrm{l} \\
(140 \mathrm{mg} / \mathrm{dl}) \text { and }<200 \mathrm{mg} / \mathrm{dl}(11.1 \mathrm{mmol} / \mathrm{l})\end{array}$ \\
\hline & $\begin{array}{l}\text { Abnormal fasting glucose levels } \\
\text { level of fasting glucose } \geq 110 \mathrm{mg} / \mathrm{dl}(\geq 6.1 \mathrm{mmol} / \mathrm{l}) \text { and }<126 \mathrm{mg} / \mathrm{dl}(7 \mathrm{mmol} / \mathrm{l}) \text { or glycaemia } 2 \mathrm{~h} \\
\text { after glucose load }<140 \mathrm{mg} / \mathrm{dl}(7.8 \mathrm{mmol} / \mathrm{l})\end{array}$ \\
\hline & $\begin{array}{l}\text { Insulin resistance } \\
\text { glucose uptake level of less than the lowest quartile for the population examined under } \\
\text { hyperinsulinaemic-euglycaemic clamp conditions }\end{array}$ \\
\hline \multicolumn{2}{|r|}{ At least 2 of the following components: } \\
\hline \multirow{4}{*}{$\begin{array}{l}\text { Additional } \\
\text { criteria }\end{array}$} & $\begin{array}{l}\text { Central obesity } \\
\text { WHR }>0.9 \text { males; }>0.85 \text { females and } / \text { or } B M I>30 \mathrm{~kg} / \mathrm{m}^{2}\end{array}$ \\
\hline & $\begin{array}{l}\text { Dyslipidaemia } \\
\text { triglycerides } \geq 1.7 \mathrm{mmol} / \mathrm{l}(\geq 150 \mathrm{mg} / \mathrm{dl}) \text { and/or } \mathrm{HDL}<0.9 \mathrm{mmol} / \mathrm{l}(<35 \mathrm{mg} / \mathrm{dl}) \mathrm{males} ;<1.0 \mathrm{mmol} / \mathrm{l} \\
(<39 \mathrm{mg} / \mathrm{dl}) \text { females }\end{array}$ \\
\hline & $\begin{array}{l}\text { Arterial blood pressure } \geq 140 / 90 \mathrm{~mm} \mathrm{Hg} \text { (verified with } \geq 160 / 90 \mathrm{~mm} \mathrm{Hg} \text { ) and/or controlled arterial } \\
\text { hypertension }\end{array}$ \\
\hline & $\begin{array}{l}\text { Microalbuminuria (excretion of albumin with urine) } \geq 20 \mu \mathrm{g} / \mathrm{min} \text { or albumin-to-creatinine ratio } \\
\geq 30 \mathrm{mg} / \mathrm{g}\end{array}$ \\
\hline
\end{tabular}

Table 2. Definition of metabolic syndrome according to the EGIR [17]

\begin{tabular}{|c|c|}
\hline \multirow{2}{*}{$\begin{array}{l}\text { Indispensable } \\
\text { criteria }\end{array}$} & Insulin resistance \\
\hline & Plasma insulin level $>75$ percentile \\
\hline \multirow{5}{*}{ Additional criteria } & At least 2 of following components: \\
\hline & $\begin{array}{l}\text { Central obesity } \\
\text { Waist circumference } \geq 94 \mathrm{~cm} \text { males; } \geq 80 \mathrm{~cm} \text { females }\end{array}$ \\
\hline & $\begin{array}{l}\text { Dyslipidaemia } \\
\text { Triglycerides } \geq 150 \mathrm{mg} / \mathrm{dl}(\geq 1.7 \mathrm{mmol} / \mathrm{l}) \text { and/or } \mathrm{HDL}<39 \mathrm{mg} / \mathrm{dl}(<1.0 \mathrm{mmol} / \mathrm{l}) \text { in males } \\
\text { and females }\end{array}$ \\
\hline & Arterial blood pressure $\geq 140 / 90 \mathrm{~mm} \mathrm{Hg}$ and/or controlled arterial blood pressure \\
\hline & Fasting glycaemia $\geq 110 \mathrm{mg} / \mathrm{dl}(\geq 6.1 \mathrm{mmol} / \mathrm{l})$ IGF or IGT, but not diabetes \\
\hline
\end{tabular}

resigning from microalbuminuria as a poorly useful criterion. Abdominal obesity is the primary factor in the development of metabolic syndrome [17-19]. The need for the determination of insulin resistance still remained a limitation in clinical practice. Also, the exclusion of patients with diabetes met with criticism, considering that they were diagnosed with many symptoms of metabolic syndrome $[17,20]$.

In 2001, the authors of the Third Report of the National Cholesterol Education Programme [NCEP], Expert Panel on Detection, Evaluation, and Treatment of High Blood Cholesterol in Adults, Adult Treatment Panel III
ATP III proposed alternative criteria for defining metabolic syndrome [21, 22]. In the guidelines by the NCEP-ATP III, the confirmation of insulin resistance was discontinued due to the lack of routine use of the measurement of insulin resistance, as well as less specific glucose tolerance test in everyday clinical practice. In the report a position was expressed that metabolic syndrome is closely related with insulin resistance; however, one major pathogenetic factor was not indicated, which is reflected by the specified diagnostic criteria (Table 3). Metabolic syndrome is diagnosed by confirmation of at least three out of 
Table 3. Definition of metabolic syndrome according to the NCEP-ATP III [21, 22]

\begin{tabular}{|c|c|}
\hline \multirow{6}{*}{$\begin{array}{l}\text { Indispensable } \\
\text { criteria }\end{array}$} & None, but any 3 of the following 5 features \\
\hline & $\begin{array}{l}\text { Central obesity } \\
\text { waist circumference - males: }>102 \mathrm{~cm} \text {; females: }>88 \mathrm{~cm}\end{array}$ \\
\hline & Triglycerides level $\geq 150 \mathrm{mg} / \mathrm{dl}(\geq 1.7 \mathrm{mmol} / \mathrm{l})$ \\
\hline & HDL cholesterol level - males: $<40 \mathrm{mg} / \mathrm{dl}(<1.04 \mathrm{mmol} / \mathrm{l}) ;$ females: $<50 \mathrm{mg} / \mathrm{dl}(<1.3 \mathrm{mmol} / \mathrm{l})$ \\
\hline & Arterial blood pressure $\geq 130 / 85 \mathrm{~mm} \mathrm{Hg}$ \\
\hline & Fasting glucose level $\geq 110 \mathrm{mg} / \mathrm{dl}(\geq 6.1 \mathrm{mmol} / \mathrm{l})$; also diabetes \\
\hline
\end{tabular}

Table 4. Definition of metabolic syndrome according to AACE [24]

\begin{tabular}{|c|c|}
\hline Indispensable criteria & IGT or IGF \\
\hline \multirow[t]{6}{*}{ Additional criteria } & Any of following components: \\
\hline & Overweight or obesity: $\mathrm{BMI} \geq 25 \mathrm{~kg} / \mathrm{m}^{2}$ \\
\hline & $\begin{array}{l}\text { Dyslipidaemia } \\
\text { triglycerides level } \geq 150 \mathrm{mg} / \mathrm{dl}(\geq 1.7 \mathrm{mmol} / \mathrm{l}) \text { and/or } \\
\mathrm{HDL} \text { cholesterol level }- \text { males: }<40 \mathrm{mg} / \mathrm{dl}(<1.04 \mathrm{mmol} / \mathrm{l}) \text {; females: }<50 \mathrm{mg} / \mathrm{dl} \\
(<1.3 \mathrm{mmol} / \mathrm{l})\end{array}$ \\
\hline & Arterial blood pressure $\geq 130 / 85 \mathrm{~mm} \mathrm{Hg}$ \\
\hline & IGT or IGF, but not diabetes \\
\hline & $\begin{array}{l}\text { Additional risk factors: family history of type } 2 \text { diabetes, polycystic ovary syndrome, } \\
\text { sedentary life style, advanced age, ethnic groups at high risk for type } 2 \text { diabetes }\end{array}$ \\
\hline
\end{tabular}

five components: elevated level of fasting glucose, (or a previous diagnosis of type 2 diabetes), abdominal obesity based on the measurement of waist circumference, elevated level of HDL cholesterol, and high arterial hypertension. The criteria by the NCEP-ATP III facilitate the diagnostics of metabolic syndrome and, therefore, become more useful from the clinical aspect. Nevertheless, resigning from racial and ethnic differences in the assessment of abdominal obesity and evaluation of insulin resistance are considered to be shortcomings of the definition by the NCEP-ATP III [21-23].

In 2003, the American Association of Clinical Endocrinologists (AACE) [24] elaborated a definition that again emphasises the importance of insulin resistance as the main pathogenetic factor. Similar to the definition by the EGIR [17], the term 'insulin resistance syndrome' was used. The major diagnostic criteria indicated by the AACE are as follows: impaired glucose tolerance, elevated level of triglycerides, low HDL cholesterol level, arterial hypertension, and obesity. However, the required minimum number of disorders confirming metabolic syndrome was not specified. The diagnosis was left to clinical evaluation. The experts of this organisation supplemented the definition of insulin resistance by additional metabolic syndrome risk factors; some of them, e.g. physical activity, create difficulties in quantitative evaluation and depend on individual assessment (Table 4). Poorly defined diagnostic criteria by the AACE result in a low scale of their application.

In 2005, the International Diabetes Federation (IDF) provided new diagnostic criteria for diagnosing metabolic syndrome, which constituted modified guidelines by the NCEA-ATP III experts [25].

According to the definition by the IDF (Table 5), metabolic syndrome is diagnosed by abdominal obesity and, additionally, two from among four components determined based on similar principles of previously adopted NCEP-ATP III criteria. The changes introduced concerned primarily visceral obesity, the assessment of which includes racial and ethnic differences. The definition by the IDF accentuates the role of abdominal obesity as the main factor of metabolic syndrome [25]. The advantage of the definition by the IDF is simplicity, and the changes introduced aimed at the facilitation of the diagnostics of metabolic syndrome and identification of individuals at increased risk of development of cardiovascular diseases and type 2 diabetes. The IDF experts presented a so-called 'platinum standard', indicating additional criteria related with metabolic syndrome. The determination of these criteria should be considered in both scientific and epidemiological studies to verify their predictive value for cardiovascular diseases and diabetes [25]. 
Table 5. Definition of metabolic syndrome according to IDF [25]

\begin{tabular}{|c|c|}
\hline Indispensable criteria & $\begin{array}{l}\text { Central obesity } \\
\text { waist circumference - males: }>94 \mathrm{~cm} \text {; females: }>80 \mathrm{~cm} \text { in European population; and } \\
\text { specific values for other ethnic groups. If BMI is }>30 \mathrm{~kg} / \mathrm{m}^{2} \text {, measurement of waist } \\
\text { circumference is not necessary for diagnosing central obesity }\end{array}$ \\
\hline \multirow[t]{5}{*}{ Additional criteria } & At least 2 of 4 components: \\
\hline & Triglycerides level $\geq 150 \mathrm{mg} / \mathrm{dl}(\geq 1.7 \mathrm{mmol} / \mathrm{l})$ or hypertriglyceridaemia control \\
\hline & $\begin{array}{l}\text { HDL cholesterol level }- \text { males: }<40 \mathrm{mg} / \mathrm{dl}(<1.03 \mathrm{mmol} / \mathrm{l}) ; \text { females: }<50 \mathrm{mg} / \mathrm{dl} \\
(<1.29 \mathrm{mmol} / \mathrm{L}) \text { or control of low HDL-C level }\end{array}$ \\
\hline & $\begin{array}{l}\text { Arterial blood pressure: systolic } \geq 130 \mathrm{~mm} \mathrm{Hg} \text { or diastolic } \geq 85 \mathrm{~mm} \mathrm{Hg} \text {, or control of } \\
\text { previously diagnosed arterial hypertension }\end{array}$ \\
\hline & $\begin{array}{l}\text { fasting glucose level } \geq 100 \mathrm{mg} / \mathrm{dl} \text { ( } \geq 5.6 \mathrm{mmol} / \mathrm{l}) \text {; or previous diagnosis of diabetes. If } \\
\text { fasting glucose level is higher than above-quoted, oral glucose tolerance test is required } \\
\text { (OGTT), which is not necessary for diagnosis of metabolic syndrome. }\end{array}$ \\
\hline
\end{tabular}

Table 6. Modified NCEP-ATP III criteria for the metabolic syndrome according to ANA/NHBLI [20]

\begin{tabular}{|c|c|}
\hline \multirow{6}{*}{$\begin{array}{l}\text { Indispensable } \\
\text { condition }\end{array}$} & None, but any 3 of the following 5 features \\
\hline & $\begin{array}{l}\text { Central obesity } \\
\text { waist circumference - males: }>102 \mathrm{~cm} \text {; females: }>88 \mathrm{~cm}\end{array}$ \\
\hline & Triglycerides level $\geq 150 \mathrm{mg} / \mathrm{dl}(\geq 1.7 \mathrm{mmol} / \mathrm{l})$ or hypertriglyceridaemia control \\
\hline & $\begin{array}{l}\mathrm{HDL} \text { cholesterol level }- \text { males: }<40 \mathrm{mg} / \mathrm{dl}(<1.03 \mathrm{mmol} / \mathrm{l}) \text {; females: }<50 \mathrm{mg} / \mathrm{dl}(<1.3 \mathrm{mmol} / \mathrm{l}) \text { or } \\
\text { control of low HDL cholesterol level }\end{array}$ \\
\hline & $\begin{array}{l}\text { Elevated arterial blood pressure: systolic } \geq 130 \mathrm{~mm} \mathrm{Hg} \text { or diastolic } \geq 85 \mathrm{~mm} \mathrm{Hg} \text { or hypertensive } \\
\text { treatment in patients with arterial hypertension }\end{array}$ \\
\hline & fasting glucose level $\geq 100 \mathrm{mg} / \mathrm{dl}(\geq 5.9 \mathrm{mmol} / \mathrm{l})$ or use blood glucose lowering medications \\
\hline
\end{tabular}

Table 7. Modified IDF criteria in association with the AHA/NHLBI of 2009 [26]

\begin{tabular}{|c|c|}
\hline \multirow{6}{*}{$\begin{array}{l}\text { Indispensable } \\
\text { criteria }\end{array}$} & At least 3 of following components: \\
\hline & $\begin{array}{l}\text { Waist circumference (according to population group): } \\
\text { Caucasian } \geq 94 \mathrm{~cm}(\mathrm{M}), \geq 80 \mathrm{~cm}(\mathrm{~F}) \\
\text { American (USA, Canada) } \geq 102 \mathrm{~cm}(\mathrm{M}), 88 \mathrm{~cm}(\mathrm{~F}) \\
\text { Middle East and countries of Mediterranean Basin } \geq 94 \mathrm{~cm}(\mathrm{M}), 80 \mathrm{~cm}(\mathrm{~F}) \\
\text { Asian } \geq 90 \mathrm{~cm}(\mathrm{M}), \geq 80 \mathrm{~cm}(\mathrm{~F})\end{array}$ \\
\hline & Triglycerides level $\geq 150 \mathrm{mg} / \mathrm{dl}$ or hypolipaemic treatment applied \\
\hline & HDL cholesterol level $<40 \mathrm{mg} / \mathrm{dl}(\mathrm{M}),<50 \mathrm{mg} / \mathrm{dl}$ (F) or treatment applied \\
\hline & Arterial blood pressure $\geq 130 / 85$ or hypotensive treatment \\
\hline & Glycaemia $\geq 100 \mathrm{mg} / \mathrm{dl}$ or hypoglycaemic treatment \\
\hline
\end{tabular}

Also in 2005, the American Heart Association (AHA) and the National Heart, Lung and Blood Institute (NHLBI) announced a somewhat modified version of the NCEP-ATP III criteria of 2001. New guidelines by the AHA/NHLBI (Table 6) do not indicate one pathogenetic factor, and for making the diagnosis of metabolic syndrome it was necessary to diagnose three out of five metabolic disorders (determined in 2001), in which the threshold values of the original definition were modified [20].
Unspecified diagnostic criteria discredited the prognostic and clinical usefulness in diagnosing metabolic syndrome, which evoked discussion in scientific circles. In response, in 2009 the IDF in association with AHA/NHLBI defined the criteria of metabolic syndrome (Table 7 ). In accordance with this definition, metabolic syndrome is verified by three out of five factors: central obesity (defined by waist circumference), increased levels of triglycerides ( $\geq 150 \mathrm{mg} / \mathrm{dl})$, low level of HDL cholesterol $(<40 \mathrm{mg} / \mathrm{dl}$ for males and 
$<50 \mathrm{mg} / \mathrm{dl}$ for females), elevated values of arterial hypertension $(\geq 130 / 85)$, and abnormal fasting glucose levels ( $\geq 100 \mathrm{mg} / \mathrm{dl}$ ), without indicating the dominant pathogenetic factor [26].

\section{Pathogenesis}

Metabolic syndrome is a cluster of mutually related metabolic factors, such as obesity, impaired glucose tolerance, lipid disorders, arterial hypertension, and prothrombotic and pro-inflammatory state increasing the risk of the development of atherosclerosis and type 2 diabetes and their cardiovascular complications [20]. Among the most important aetiological factors of metabolic syndrome are mutually closely related abdominal obesity and insulin resistance [14, 20, 27]. There is also a general view that for the development of metabolic syndrome, genetic predispositions and environmental factors, including high calorie and atherogenic diet, and low physical activity, are responsible. A high diversity within the population is emphasised, from the aspect of both the genetic background and different gene expression in response to various environmental factors [28]. To the genetic factors of the development of metabolic syndrome belong genes, the mutations of which are responsible for individual components of this syndrome, primarily such polymorphic forms of genes, the expression of which may lead to the occurrence of obesity [29], insulin resistance, and carbohydrates metabolism disorders, as well as arterial hypertension [30, 31]. Studies conducted in recent years indicate the inflammatory process as the factor combining obesity, and insulin resistance and atherosclerosis [32]. An increasing role of adipokines in the pathogenesis of metabolic syndrome provides a new reason for the undertaken search for the relationship between the key element of metabolic syndrome - visceral obesity, and the remaining disorders that accompany this syndrome [33].

\section{Epidemiology of metabolic syndrome and occupational efficiency}

Diagnostic criteria developed by experts from various organisations, e.g. the WHO, through EGIR, NCEP-ATP III, AACE, IDF, AHA, and NHLBI, are still an issue for many discussions and consideration. The adopted threshold values and its components differ, as well as the pathogenetic factors indicated in this pathological entity. The above-mentioned situation is translated into frequent difficulties in the identification of metabolic syndrome, and the determination of the optimum method of its treatment.

Nevertheless, it is an undisputed fact that metabolic syndrome constitutes a risk factor for cardiovascular diseases and type 2 diabetes, and exerts an effect on an increase in the general mortality rate and mortality from cardiovascular causes [34-36]. In patients with metabolic syndrome, cardiovascular death is observed 3.5-5.5 times more frequently than in the general population [35, 36]. The epidemic of obesity, which has been observed worldwide, affects the dynamics of the occurrence of metabolic syndrome [14, 22, 27].

The considerable prevalence of metabolic syndrome in Poland is confirmed by the results of epidemiological studies. The extent of this phenomenon is determined by the NATPOL PLUS and WOBASZ studies carried out in a representative group of the Polish population. The evaluation was performed using the NCEP-ATP III criteria of 2001, and their more recent version of 2005. The results of studies show that metabolic syndrome occurs with moderate intensity in every fifth adult $[37,38]$. Arterial hypertension was most frequently noted among the analysed symptoms of metabolic syndrome [37]. Based on observations carried out within the international project Pol-MONICA, it was found that the frequency of occurrence of metabolic syndrome among the Polish population is increasing [39].

The scale of occurrence of metabolic syndrome - complications and fatal consequences - confirmed by epidemiological studies points towards considerations concerning the effect of the existing phenomenon on the professional aptitude and competence of the population at productivity age. From the aspect of ergonomics of work, quality of services provided, and economy this problem seems to be important and encourages scientific studies in this area. Why?

Obesity is a metabolic disease, and an intensifying and prolonged pathological process causing pathologies and dysfunctions affecting nearly all systems and organs of the human body. This results in disability and the risk of a shortened lifespan [40]. The results of the Pol-MONICA study, which covered a population aged 35-64 years, demonstrated that in Poland overweight is found in $45.2 \%$ of males and $35.1 \%$ of females, and obesity - in $22.4 \%$ of males and $29 \%$ of females [38]. Arterial hypertension remains a widely prevalent risk factor of cardiovascular system diseases. Uncontrolled hypertension leads to the development of organ complications. Clinical symptoms of hypertension cover advanced atherosclerosis, myocardial hypertrophy with secondary heart failure, myocardial infarction, cerebral stroke, and renal failure. According to the NATPOL PLUS study [38], 29\% of adult males and $29 \%$ of adult females suffer from hypertension, and in $40 \%$ of males and $27 \%$ of females it is not detected. In the WOBASZ study [37] hypertension was more frequent, and it was noted in $42.1 \%$ of males and $32.9 \%$ of females. Insulin resistance of various degrees was found in approximately $50 \%$ of adults living in highly industrialised countries [41]. Insulin resistance is most often diagnosed in disorders such as: type 2 diabetes, arterial hypertension, and renal failure. In obese patients, especially those with abdominal obesity and overweight, the resistance to the effect of this 
hormone was confirmed [40]. According to data from the WHO, at present there are approximately 180 million diabetic patients, and it is expected that by 2025 this number will increase to more than 300 million. Recently, diabetes, as well as cardiovascular system diseases, is one of the most serious health risks [42]. The most frequent form of diabetes is type 2 , which develops mainly among adults aged over 45 years. It is diagnosed in approximately $90 \%$ of all patients with diabetes. The main life threat for patients with this disorder is the development of chronic complications. A big problem is also vascular disease of the lower extremities, which is one of the main causes for amputation of limbs among the adult population. In turn, a major cause of blindness and severe renal failure in adults is changes in the microcirculation specific for diabetes, which is manifested by retinopathy and diabetic nephropathy $[43,44]$.

Dyslipidaemia remains the most prevalent cardiovascular risk factor in Poland, and its most frequent form is hypercholesterolaemia. This was confirmed by the results of the study conducted during the period 2004-2010 within the programme LIPIDOGRAM 5 YEARS. The need to increase and improve the control of dyslipidaemia treatment in Poland is confirmed by the insufficient effectiveness in the reduction of lipidogram parameters among nearly $50 \%$ of patients with levels of total cholesterol higher than normal, and in more than $30 \%$ of individuals with elevated levels of LDL-cholesterol and triglycerides [45]. It was confirmed that regular physical activity favourably modifies all components of metabolic syndrome and is associated with a decrease in the risk of development of cardiovascular diseases on the atherosclerotic background [46] and the risk of contracting type 2 diabetes in individuals with abnormal glucose tolerance [47]. Despite the widely popularised importance of physical activity for health, Poles lead a lifestyle far from health promoting. The results of studies by the Central Bureau for Public Opinion (CBOS) of 2012, 'Poles about their health and health-promoting behaviours and activities 2012', showed evidence of a low level of physical activity in society. As many as $61 \%$ of respondents admitted that they never or almost never perform such exercises as gymnastics, aerobics, or go to a gym, and nearly half of respondents $(47 \%)$ reported that they avoid such activities as running, swimming, riding a bicycle, or team games [48].

Scientific and epidemiological studies indicate a growing problem of the epidemic of metabolic syndrome, as well as its individual components as independent risk factors. The symptoms and effects of the above-mentioned disorders create a threat for professional competence (the system of psychological and physical capabilities) for individual occupational groups performing both physical and intellectual work. It seems that the occurring pathological entities are a barrier for meeting the requirements posed by the work environment, i.e. limiting professional aptitude. Metabolic syndrome indicates many burdens and limitations, both psychological and physical, for the occupationally active population, which is certainly translated into a lower quality of services provided.

The disorders discussed have serious consequences of psychological and economic nature, affecting patients, healthcare systems and occupational schemes. An increased interest in metabolic syndrome resulting from the awareness of health hazards brought about by obesity should also be a determinant of research concerning the assessment of professional aptitude and the degree of productivity of the Polish population. The subsequent problems arising are the costs of reduced productivity resulting from work absenteeism, workdays lost as a result of retirement or health benefit, as well as premature mortality due to metabolic syndrome.

\section{Summing up}

The precise recognition of both genetic and environmental factors leading to the development of metabolic syndrome, and proper determination of the character and usefulness of the features of metabolic syndrome in clinical practice, still remain problems to be solved. In accordance with the latest report by the WHO, metabolic syndrome should be perceived as a premorbid state, and the superior goal is concern about adequate health and nutrition education, and the modification of the to-date lifestyle in order to limit the occurrence of this cause-effect system.

At present, a tendency is observed towards paying attention mainly to the evaluation of the direct medical costs related with treatment; therefore, it seems justifiable to consider the effects of professional limitations resulting from metabolic disorders, which are translated into the load for the economic and healthcare systems.

\section{Conflict of interest}

The authors declare no conflict of interest.

\section{References}

1. Goldwyn RM. Nicolaas TULP (1593-1674). Med Hist 1961; 5: 270-6.

2. Erkelens DW, de Bruin TW, Castro Cabezas M. Tulp syndrome. Lancet 1993; 342: 1536-7.

3. Enzi G, Busetto L, Inelmen EM, et al. Historical perspective: visceral obesity and related comorbidity in Joannes Baptista Morgagni's 'De sedibus et causis morborum per anatomen indagata'. Int J Obes Relat Metab Disord 2003; 27: 534-5.

4. Kylin E. Studien über das Hypertonie-HyperglykämieHyperurikämiesyndrom. Zentralblatt für Innere Medizin 1923; 44: 105-27. 
5. Avogaro P, Crepaldi G, Enzi G, Tiengo A. Association of hyperlipidemia an mild obesity. Acta Diabetol Lat 1967; 4: $36-41$.

6. Węgierko J. Diabetes mellitus. PZWL, Warsaw 1954.

7. Węgierko J. Znaczenie praktyczne podziału cukrzycy na poszczególne jej postacie. Pol Arch Med Wewn 1955; 25 : 791-7.

8. Szotowska M, Więcek A. Zespół metaboliczny. Terapia 2006; 7/8: 27-36.

9. Hanefeld M, Leonhardt W. Das metabolische Syndrome. Dt. Gesundh-Wesen1981; 36: 545-51.

10. Reaven GM. Banting Lecture 1988. Role of insulin resistance in human disease. Diabetes 1988; 37: 1595-607.

11. Kaplan NM. The deadly quartet. Upper-body obesity, glucose intolerance, hypertriglyceridemia, and hypertension. Arch Intern Med 1989; 149: 1514-20.

12. Ferrannini E, Buzzigoli G, Bonadonna R, et al. Insulin resistance in essential hypertension. N Engl J Med 1987; 317: 350-7.

13. Wyrzykowski B. Historia zespołu metabolicznego. Choroby Serca i Naczyń 2005; 4: 206-13.

14. Lemieux I, Pascot A, Couillard C, et al. Hypertriglyceridemic waist: a marker of the atherogenic metabolic triad (hyperinsulinemia; hyperapolipoprotein B; small, dense LDL) in men? Circulation 2000; 102: 179-84.

15. Alberti KG, Zimmet PZ. Defi nition, diagnosis and classifi cation of diabetes mellitus and its complications. Part 1: diagnosis and classification of diabetes mellitus: provisional report of WHO consultation. Diabetes Med 1998; 15: 539-53.

16. Grundy SM, Hansen B, Smith SC, et al. Clinical management of metabolic syndrome. Report of the American Association/National Heart, Lung, and Blood Institute/ American Diabetes Association conference on scientific issues related to management. Circulation 2004; 109: 551-6.

17. Balkau B, Charles MA. Comment of the provisional report from the WHO consultation. European Group for the Study of Insulin Resistance (EGIR). Diabet Med 1999; 16: 442-3.

18. Balkau B, Charles MA, Drivsholm T, et al. The European Group for the Study of Insulin Resistance (EGIR): Frequency of the WHO metabolic syndrome in European cohorts, and an alternative definition of an insulin resistance syndrome. Diabetes Metab 2002; 28: 364-76.

19. Lewis GF, Carpentier A, Adeli K, et al. Disordered fat storage and mobilization in the pathogenesis of insulin resistance and type 2 diabetes. Endocr Rev 2002; 23: 201-29.

20. Grundy SM, Cleeman JI, Daniels SR, et al. Diagnosis and management of the metabolic syndrome. An American Heart Association/National Heart, Lung, and Blood Institute Scientific Statement. Circulation 2005; 112: 2735-52.

21. Executive Summary of the Third Report of the National Cholesterol Education Program (NCEP) expert Panel on detection, evaluation, and treatment of high blood cholesterol in adults (Adult Treatment Panel III). JAMA 2001; 285: 2486-97.

22. National Cholesterol Education Program National Heart, Lung, and Blood Institutes of Health NIH Publication No. 02-5215 September 2002: Third report of the National Cholesterol Education Program (NCEP) expert panel on detection, evaluation, and treatment of high blood cholesterol in adults (Adult Treatment Panel III) final report. Circulation 2002; 106: 3143-421.
23. Liao Y, Kwon S, Shaughnessy S, et al. Critical evaluation of Adult Treatment Panel III criteria in identifying insulin resistance with dyslipidemia. Diabetes Care 2004; 27: 978-83.

24. Einhorn D, Reaven GM, Cobin RH, et al. American College of Endocrinology position statement on the insulin resistance syndrome. Endocr Pract 2003; 9: 237-52.

25. Alberti G, Zimmet PZ, Shaw J, et al. International Diabetes Federation 2006: the IDF consensus worldwide definition of the metabolic syndrome. http://www.idf.org/webdata/docs/IDF_Meta_def_fi nal.pdf (23.06.2015).

26. Alberti KG, Eckel RH, Grundy SM, et al. Harmonizing the metabolic syndrome. A joint interim statement of the International Diabetes Federation Task Force on Epidemiology and Prevention; National Heart, Lung, and Blood Institute; American Heart Association; World Heart Federation; International Atherosclerosis Society; and International Association for the Study of Obesity. Circulation 2009; 120: 1640-5.

27. Carr DB, Utzschneider KM, Hull RL, et al. Intraabdominal fat is a major determinant of the National Cholesterol Education Program Adult Treatment Panel III criteria for the metabolic syndrome. Diabetes 2004; 53: 2087-94.

28. Gale EA. The myth of the metabolic syndrome. Diabetologia 2005; 48: 1679-83.

29. Snyder EE, Walts B, Perusse L, et al. The human obesity gene map: the 2003 update. Obes Res 2004; 12: 369-439.

30. Stein CM, Song Y, Elston RC, et al. Structural equation model-based genome scan for the metabolic syndrome. BMC Genet 2003; 4 (Supp1. 1): S99.

31. Tang W, Miller MB, Rich SS, et al. Linkage analysis of a composite factor for the multiple metabolic syndrome: the National Heart, Lung, and Blood Institute Family Heart Study. Diabetes 2003; 52: 2840-7.

32. Semenkovich CF. Insulin resistance and atherosclerosis. J Clin Invest 2006; 116: 1813-22.

33. Pacholczyk M, Ferenc T, Kowalski J. Zespół metaboliczny. Część II: patogeneza zespołu metabolicznego i jego powikłań. Postępy Hig Med Dosw 2008; 62: 543-58.

34. Ford ES. Risk for all-cause mortality, cardiovascular disease, and diabetes associated with the metabolic syndrome. A summary of the evidence. Diabetes Care 2005; 28: $1769-78$

35. Isomaa B, Almgren P, Tuomi T, et al. Cardiovascular morbidity and mortality associated with the metabolic syndrome. Diabetes Care 2001; 24: 683-9.

36. Lakka HM, Laaksonen DE, Lakka TA, et al. The metabolic syndrome and total and cardiovascular disease mortality in middle-aged men. JAMA 2002; 288: 2709-16.

37. Wyrzykowski B, Zdrojewski T, Sygnowska E, et al. Epidemiologia zespołu metabolicznego w Polsce. Wyniki programu WOBASZ. Kardiol Pol 2005; 63 (Suppl. 4): 1-4.

38. Zdrojewski T, Bandosz P, Szpakowski P, et al. Rozpowszechnienie głównych czynników ryzyka chorób układu sercowo-naczyniowego w Polsce. Wyniki badania NATPOL PLUS. Kardiol Pol 2004; 61 (Suppl. IV): IV1-26.

39. Broda G, Szcześniewska D, Rywik S. Częstość występowania zespołu metabolicznego w populacji osób dorosłych Warszawy. Med Metab 2003; 7: 225-9.

40. Tatoń J, Czech A, Bernas M. Otyłość: zespół metaboliczny. Wyd. Lekarskie PZWL, Warsaw 2007; 26-350.

41. Cymerys M, Pupek-Musialik D. Nowe czynniki ryzyka wieńcowego u otyłych chorych z zespołem metabolicznym. In: Otyłość i zespół metaboliczny od teorii do prak- 
tyki. Pupek-Musialik D (ed.). Via Medica, Gdansk 2007; 66-77.

42. King H, Aubert R, Herman W. Global burden of diabetes, 1995-2025: prevalence, numerical estimates, and projections. Diabetes Care 1998; 21: 1414-31.

43. Jarret RJ, Shipley MJ. Type 2 (non-insulin-dependent) diabetes mellitus and cardiovascular disease - putative association via common antecedens: further evidence from the Whitehall Study. Diabetologia 1988; 31: 737-41.

44. Janeczko D, Kopczyński J, Lewandowski Z, et al. Umieralność z powodu chorób układu krążenia u chorych na cukrzycę typu 2. Przegląd Lek 2000; 57 (Suppl. 4): 3.

45. LIPIDOGRAM 5 LAT - Ogólnopolskie badanie epidemiologiczne zaburzeń lipidowych oraz wybranych czynników ryzyka chorób sercowo-naczyniowych w warunkach Podstawowej Opieki Zdrowotnej. KLRWP, Poznań 2013; available at: http://www.termedia.pl (29.06.2015).

46. Thompson PD, Buchner D, Pina IL, et al. Exercise and physical activity in the prevention and treatment of atherosclerotic cardiovascular disease. A statement from the Council on Clinical Cardiology (Subcommittee on Exercise, Rehabilitation and Prevention) and the Council on Nutrition, Physical Activity and Metabolism (Subcommittee on Physical Activity). Circulation 2003; 107: 3109-16.

47. Knowler WC, Barrett-Connor E, Fowler SE, et al. Reduction in the incidence of type 2 diabetes with lifestyle intervention or metformin. N Engl J Med 2002; 346: 393-403.

48. http://www.cbos.pl/SPISKOM.POL/2012/K_110_12.PDF (29.06.2015)

\section{Address for correspondence:}

\section{Dorota Rębak PhD}

Department of Surgery and Surgical Nursing with Research Laboratory Faculty of Health Sciences Jan Kochanowski University al. IX Wieków Kielc 19, 25-317 Kielce, Poland Phone: +48 501321304

Fax: +48 413496916

E-mail: dorotar@ujk.edu.pl 